\title{
Digital Discrimination: The Case of Airbnb.com
}

\author{
Benjamin Edelman ${ }^{1}$ and Michael Luca ${ }^{2}$
}

\begin{abstract}
Online marketplaces often contain information not only about products, but also about the people selling the products. In an effort to facilitate trust, many platforms encourage sellers to provide personal profiles and even to post pictures of themselves. However, these features may also facilitate discrimination based on sellers' race, gender, age, or other aspects of appearance. In this paper, we test for racial discrimination against landlords in the online rental marketplace Airbnb.com. Using a new data set combining pictures of all New York City landlords on Airbnb with their rental prices and information about quality of the rentals, we show that non-black hosts charge approximately $12 \%$ more than black hosts for the equivalent rental. These effects are robust when controlling for all information visible in the Airbnb marketplace. These findings highlight the prevalence of discrimination in online marketplaces, suggesting an important unintended consequence of a seemingly-routine mechanism for building trust.
\end{abstract}

\footnotetext{
${ }^{1}$ Harvard Business School, bedelman@hbs.edu

${ }^{2}$ Harvard Business School, mluca@hbs.edu
} 


\section{Introduction}

Online marketplaces have become increasingly common. Beyond the early platforms such as eBay and Amazon, specialized marketplaces have proliferatedAirbnb, RelayRides, oDesk, and dozens more-with strikingly rapid growth. The success of these companies relies on their ability to create trust between buyers and sellers - assurance that an apartment, car, or coder will actually perform as expected. To build trust and facilitate transactions, online markets typically present information not only about products, but also about the people offering the products. Many platforms now allow sellers to present personal profiles, post pictures of themselves, and even link to their Facebook accounts, leveraging social media to establish reputation and build trust. While these features serve the laudable goals of trust-building and accountability, they can also bring unintended consequences: personal profiles may facilitate discrimination.

In this paper, we empirically investigate the extent of racial discrimination against hosts on the popular online rental marketplace Airbnb.com. Since its founding in 2008, Airbnb has facilitated over two million room rentals, and investors valued Airbnb at roughly $\$ 2.5$ billion as of October 2012. Transactions on Airbnb are inherently riskyarranging short-term tenants for rooms in apartments and houses, or even entire dwellings. To facilitate these transactions, Airbnb offers a robust user reputation system including quantitative and qualitative reviews of both guests and hosts. One prominent feature of Airbnb's review system is that hosts and guests post public profiles, including their pictures and first names-potentially facilitating not only trust, but also discrimination. 
To investigate the extent of discrimination, we construct a new data set combining pictures of all New York City landlords on Airbnb with their rental prices and information about characteristics and quality of their properties, and we use that data set to measure the magnitude of discrimination on Airbnb. We find that non-black hosts are able to charge approximately $12 \%$ more than black hosts, holding location, rental characteristics, and quality constant. Moreover, black hosts receive a larger price penalty for having a poor location score relative to non-black hosts. These differences highlight the risk of discrimination in online marketplaces, suggesting an important unintended consequence of a seemingly-routine mechanism for building trust.

\section{About Airbnb}

Airbnb.com is a popular online marketplace for short-term rentals. Airbnb was founded in 2008 and gained traction quickly. As of 2013, Airbnb has 300,000 listings, comparable in total size to Marriott's 535,000 rooms worldwide.

A guest seeking to rent a room or property on Airbnb can enter the desired destination and dates, then view a variety of options including property type (entire dwelling versus a single room), general location, other property features and characteristics, price, and availability. Figures 1a through 1c present screenshots of key steps in the search process, including initial listings (1a), search filters (1b), and a property listing page (1c) including listing details, host photo and name, and reviews from prior guests. To book a room or property, the guest uses Airbnb's request and payment systems: Airbnb presents the guest's request to the host who accepts or rejects, and if the host accepts, Airbnb charges the guest and pays the host accordingly. 
In contrast with the traditional hotel industry (which is dominated by hotels and inns offering many rooms each), Airbnb enables anyone to post even a single vacant room online. Central to this paper, a guest sees information not only about the room the guest is renting, but also information about the host of the property, regardless of whether the host will be staying at or near the property. The hosts profile consists of a name, a picture, and an optional description, in addition to user-generated ratings of the host.

Our data set consists of a snapshot of listings contained on Airbnb for the city of New York, NY as of July 17, 2012 For each listing, we collected the price that the host is asking, the characteristics of the host, and the characteristics of the apartment. We also know how many guests have left reviews, and the average rating for each host characteristic in Airbnb's structured rating system (location rating, check-in rating, communication rating, cleanliness rating, and accuracy rating). Finally, we hired workers on Amazon Mechanical Turk to examine each listing's photos, as posted to Airbnb. AMT workers rated the quality of each listing on a seven-point scale ranging from "This is a terrible apartment. I would not stay here at any price" to "This is an extremely nice apartment. I would stay here even if it were a lot more expensive than a nice hotel room." With these variables, we control for the quality of the apartment, as observed by potential tenants on the Airbnb site.

To identify the race of the hosts on Airbnb, we downloaded all public profile pictures of New York City hosts. We hired other workers on Amazon Mechanical Turk to code the race of the hosts into one of the following categories: White, Black, Hispanic, Asian, Unclear but Non-white, Multiple Races, Not Applicable (no people in picture), or Unclear/Uncertain. 
The goal of the paper is then to empirically investigate the differences in prices between hosts of varying races. In this analysis, we focus on estimating the price gaps between black and non-black hosts.

Ideally, our analysis would consider both price and demand effects. However, the Airbnb site provides only limited information about demand (e.g. guests' reviews of a fraction of a host's prior transactions), and Airbnb was not willing to share data for this project. As a result, we forego analysis of consumer demand. Instead, we focus on the role of race in listing prices. Since the Airbnb platform includes a posted price for each listing, we collect detailed data about property prices as well as other property characteristics. Figure 2 presents the distribution of posted prices by hosts in New York City.

\section{Is Airbnb liable for discrimination?}

Airbnb decides what information to collect and distribute in light of its incentives and liability. For example, if Airbnb were liable for any discriminatory outcomes resulting from use of its platform, then Airbnb would have a strong incentive to prevent such discrimination from occurring. However, Airbnb has little incentive to reduce discrimination, which helps explain the reputation system that Airbnb has established.

In a litigation context, the posting of names and photos—with nothing more-is unlikely to create liability for platforms such as Airbnb. For example, Chicago Lawyers Committee for Civil Rights Under Law v. Craigslist Inc., 461 F. Supp. 2d 681 (N.D. Ill. Feb. 3, 2006) considers affirmative statements of racial, gender, and familial status preference ("NO MINORITIES", "No children") that are plainly unlawful under the Fair 
Housing Act—but finds that Craigslist is not the publisher or speaker of these unlawful statements since Craigslist does nothing to induce a user to post any particular listing or express any particular preference for discrimination.

In contrast, a similar case against Roommates.com found liability when Roommates.com asked users to describe their age, gender, sexual orientation, occupation and children, and then to answer similar questions about roommate preferences. Fair Housing Council of San Fernando Valley v. Roommates.com, LLC, No. CV 03-09386PA (RZX). But Airbnb's general-purpose photos fall far short of the specificity of Roommates.com's requests to its users.

In providing a mechanism for users to complete profiles and upload photos, Airbnb is unlikely to face legal considerations that affect its user interface or design. Moreover, pictures are an important part of Airbnb's design: from discussions with Airbnb guests, we understand that pictures help guests accept the Airbnb model, including staying in a property with, or offered by, a stranger. Foregoing host pictures would likely reduce some guests' willingness to use Airbnb. Hence, if Airbnb were to take action to reduce the extent of discrimination, the decision would be driven by ethics, rather than profit or the law.

\section{Empirical Analysis}

This section reports our main results. We estimate the gap in rents received by non-black and black hosts, and we show that this gap persists even when controlling for factors such as location, reviews, and photos. We then investigate other determinants of prices on Airbnb. 


\subsection{Determinants of prices on Airbnb}

The Airbnb site reports a variety of information about hosts and listings. Table 2 presents the results of a regression of price on the information presented by Airbnb. Price increases with number accommodated, location rating, and social network presence. A larger number accommodated indicates that the property is more spacious and has a larger bed or multiple beds. A larger location rating indicates that the property is in an area that is safer and/or has better entertainment options. The significant influence of consumer ratings on Airbnb is consistent with evidence in other settings where reviews are an important determinant of demand (Chevalier and Maylzin 2006, Luca 2011). Social networking presence is also important: Hosts who provide LinkedIn, Facebook, and Twitter accounts as well as phone numbers demonstrate a stable occupation, social life, and identity, all of which increase the likelihood that the host is trustworthy.

The regressions report important interactions between the number of bedrooms and access to the whole apartment. For example, if an apartment has four bedrooms but does not provide the guest the whole apartment, then the guest is likely sharing the apartment with three strangers. This scenario is less pleasant than a shared apartment with two bedrooms, in which the guest shares the apartment with only one stranger. On the other hand, if a guest has access to the whole apartment, it is better to have more bedrooms, as more bedrooms simply mean more space for the guest and companions. Throughout, the regression estimates are consistent with intuition.

Our analysis also confirms the importance of listing photos. A listing with photos rated one point larger, on our seven-point scale, is associated with a price $\$ 11.91$ greater. 
Similar effects occur when we allow a quadratic fit of photo quality and when we allow flexible indicator variables for each level of quality.

\subsection{Main result: Do black hosts earn less on Airbnb?}

This section analyzes the role of race in determining prices on Airbnb. The raw data show that non-black and black hosts receive strikingly different rents: roughly $\$ 144$ versus $\$ 107$ per night, on average. (See Table 1, row 1, right two columns.) Figure 3 shows the respective distributions of rents received by non-black black and black hosts, with the entire distribution of rents for black hosts shifted down compared to that of nonblack hosts. Table 3 finds that this difference is significant at the $1 \%$ level.

Of course, many factors influence the rents received by hosts - and race is likely correlated with some of these factors. One might be concerned that apparent racial differences actually result from unobserved differences between listings. While we cannot completely eliminate this concern, we mitigate the issue by controlling for all of the information that a guest sees when examining Airbnb search results and listing details.

Table 3 presents our main results. Column 2 controls for the main characteristics of the listing itself - the number of bedrooms and an indicator for whether the property will be shared or will be reserved solely for the guest. Column 3 then controls for a series of ratings that have been left for each host by guests. These controls allow us to remove the effects of guest perceptions of location, quality, and other factors. The only effect that is statistically significantly different from zero is location, which we allow to enter in quadratic form in Column 4. Adding these controls eliminates roughly half of 
the racial price gap (reducing the estimated effect of race from approximately $\$ 31$ to approximately \$16). Columns 5 through 7 add further controls for listing quality as evidenced by the listing photos posted to the Airbnb site. Controlling for all of these factors, non-black hosts earn roughly $12 \%$ more for a similar apartment with similar ratings and photos relative to black hosts.

\subsection{How do black and non-black hosts differ?}

It is possible that some of the discrimination seen in the previous section results from guests' perceptions that black hosts may offer properties that differ from properties being offered by non-black hosts. Indeed, the last column of Table 1 indicates that black hosts' properties tend to be located in inferior locations, and have properties that look worse (based on listing photos).

Despite guests' potential concerns about inferior properties from black hosts, we do not believe this mechanism drives our results. Importantly, our results are robust to controlling for all of the attributes that are readily observable to a potential tenant browsing listings on Airbnb.

The literature identifies distinct types of discrimination in light of mechanisms informing decision-making. In taste-based discrimination, users favor or disfavor a group based on pure user preference (here, a preference not to stay with a black host). In contrast, in statistical discrimination, a user's decision-making is grounded in inference (here, a guest inferring that a property has inferior quality, holding constant the information presented in the property listing page and reviews, because its host is black). The empirical evidence on whether discrimination is primarily statistical or taste-based is 
mixed. For example, looking at online sales of iPods on Craigslist, Doleac and Stein (forthcoming) find evidence suggesting statistical discrimination. Similarly, Pope and Sydnor (2011) present evidence of statistical discrimination on Prosper.com. Looking at medical students, Rubineau and Kang (2012) show that students exhibit more discriminatory behavior after their first year of medical school, which they present as evidence against statistical discrimination. In our setting, we are unable to fully disentangle these two forms of discrimination.

\subsection{Robustness check: Other racial differences in outcomes at Airbnb}

The prior sections compare black Airbnb hosts to all non-black Airbnb hosts (including those who our Amazon Mechanical Turk workers classified as Asian, Hispanic, unclear, multiple). Results are broadly similar in an analysis restricted only to Airbnb hosts our workers classified as white or black. Specifically, in a version of Table 3 restricted only to white and black hosts, the coefficient on black hosts remains statistically significantly negative and in all cases within $15 \%$ of the amount reported in Table 3.

\section{Discussion}

Designing an online reputation requires balancing competing interests. To most designers of online reputation systems, the key objective is improving trust and accountability—an objective typically advanced by posting additional information. But our results indicate that the same features that build trust can also have severe unintended 
consequences. In this section, we further relate our findings to the existing literature, and discuss the managerial implications of our paper.

\subsection{Does the internet reduce discrimination?}

Discrimination remains a significant policy concern in settings ranging from the workplace (Bertrand and Mullainathan 2004) to housing markets (Zhao et al 2006, Card et al 2008) to physician treatment of patients (Rubineau and Kang 2012)In principle, the rise of online marketplaces can reduce the scope of discrimination. Face-to-face interactions automatically disclose information about user identity. (For example, a candidate coming into a room for a job interview necessarily reveals gender, race, and even approximate age to the interviewer.) In contrast, digital transactions can reduce the flow of undesirable or unnecessary information. In fact, there is evidence that the internet has reduced racial discrimination in car prices (Scott Morton et al 2003), a sector with high documented rates of discrimination (Ayres and Siegelman 1995). But these benefits are not guaranteed; the benefits depend on the design of online environments.

\subsection{Discrimination as a market design problem}

Our findings contribute to the empirical market design literature on improvements to reputation systems (Dai et al 2013, Dover et al forthcoming, Luca and Zervas 2013, Bolton et al 2013). Despite the potential of the internet to reduce discrimination, our results suggest that social platforms such as Airbnb may have the opposite effect. Full of salient pictures and social profiles, these platforms make it easy to discriminate-as 
evidenced by the significant penalty faced by a black host trying to conduct business on Airbnb.

Is there hope that platforms like Airbnb will do more to curb discrimination? In the Airbnb setting, there is no fundamental reason why a guest needs see a host's picture in advance of making a booking - nor does a guest necessarily even need to know a host's name (from which race may be inferred, as in Bertrand and Mullainathan 2004). We note the many contexts in which online platforms specifically withhold information from market participants. For example, prior to purchase, an eBay buyer cannot see a seller's name or photo, nor vice versa. Indeed, Airbnb itself prohibits (and runs software to prevent) hosts and guests from sharing email addresses or phone numbers before a booking is made, lest this information exchange let parties contract directly and avoid Airbnb fees. Given Airbnb's careful consideration of what information is available to guests and hosts, Airbnb might consider eliminating or reducing the prominence of host photos: It is not immediately obvious what beneficial information these photos provide, while they risk facilitating discrimination by guests. Particularly when a guest will be renting an entire property, the guest's interaction with the host will be quite limited, and we see no real need for Airbnb to highlight the host's picture. The main barrier that we see is a lack of liability or other economic incentive: to date, no legal principle or customer demand requires or encourages Airbnb to take action to prevent discrimination. 


\section{References}

Ayres, Ian and Peter Siegelman, 1995. "Race and Gender Discrimination in Bargaining for a New Car," American Economic Review, Vol. 85, No. 3, 304-321.

Bertrand, Marianne and Sendhil Mullainathan, 2004. "Are Emily and Greg More Employable Than Lakisha and Jamal?" American Economic Review, Vol. 94, No. 4, 9911013.

Bolton, Gary, Ben Greiner, and Axel Ockenfels, 2013. "Engineering Trust: Reciprocity in the Production of Reputation Information," Management Science, Vol. 59, No. 2, 265285.

Card, David, Alexandre Mas, and Jesse Rothstein, 2008. "Tipping and the Dynamics of Segregation," Quarterly Journal of Economics, Vol. 123, No. 1, 177-218.

Chevalier, Judith and Dina Mayzlin, 2006. "The Effect of Word-of-Mouth on Sales: Online Book Reviews," Journal of Marketing Research, Vol. 43, No 3.

Dai, Weijia, Ginger Jin, Jungmin Lee, and Michael Luca, “Optimal Aggregation of Consumer Ratings: An Application to Yelp.com," working paper.

Doleac, Jennifer and Luke Stein, forthcoming. "The Visible Hand: race and Online Market Outcomes," The Economic Journal.

Luca, Michael, 2011. "Reviews, Reputation, and Revenue: The Case of Yelp.com," working paper.

Luca, Michael and Georgios Zervas, 2013. "Fake It Till You Make It: Reputation, Competition, and Yelp Review Fraud," working paper.

Pope, Devin and Justin Sydnor, 2011. "What's in a Picture? Evidence of Discrimination from Prosper.com," Journal of Human Resources, Vol. 46, No. 1, 53-92.

Rubineau, Brian and Yoon Kang, 2012. "Bias in White: A Longitudinal Natural Experiment Measuring Changes in Discrimination," Management Science, Vol. 58, No. 4, 660-677.

Scott Morton, Fiona, Florian Zettelmeyer, and Jorge Silva-Risso, 2003. "Consumer Information and Discrimination: Does the Internet Affect the Pricing of New Cars to Women and Minorities?" Quantitative Marketing and Economics, Vol. 1, No. 1, 65-92.

Zhao, Bo, Jan Ondrich, and John Yinger, 2006. "Why do real estate brokers continue to discriminate? Evidence from the 2000 Housing Discrimination Study," Journal of Urban Economics,394-419. 


\section{Figures}

\section{Figure 1a-c: The Airbnb Site}

\section{Figure 1a: Screenshot of Listings in New York}

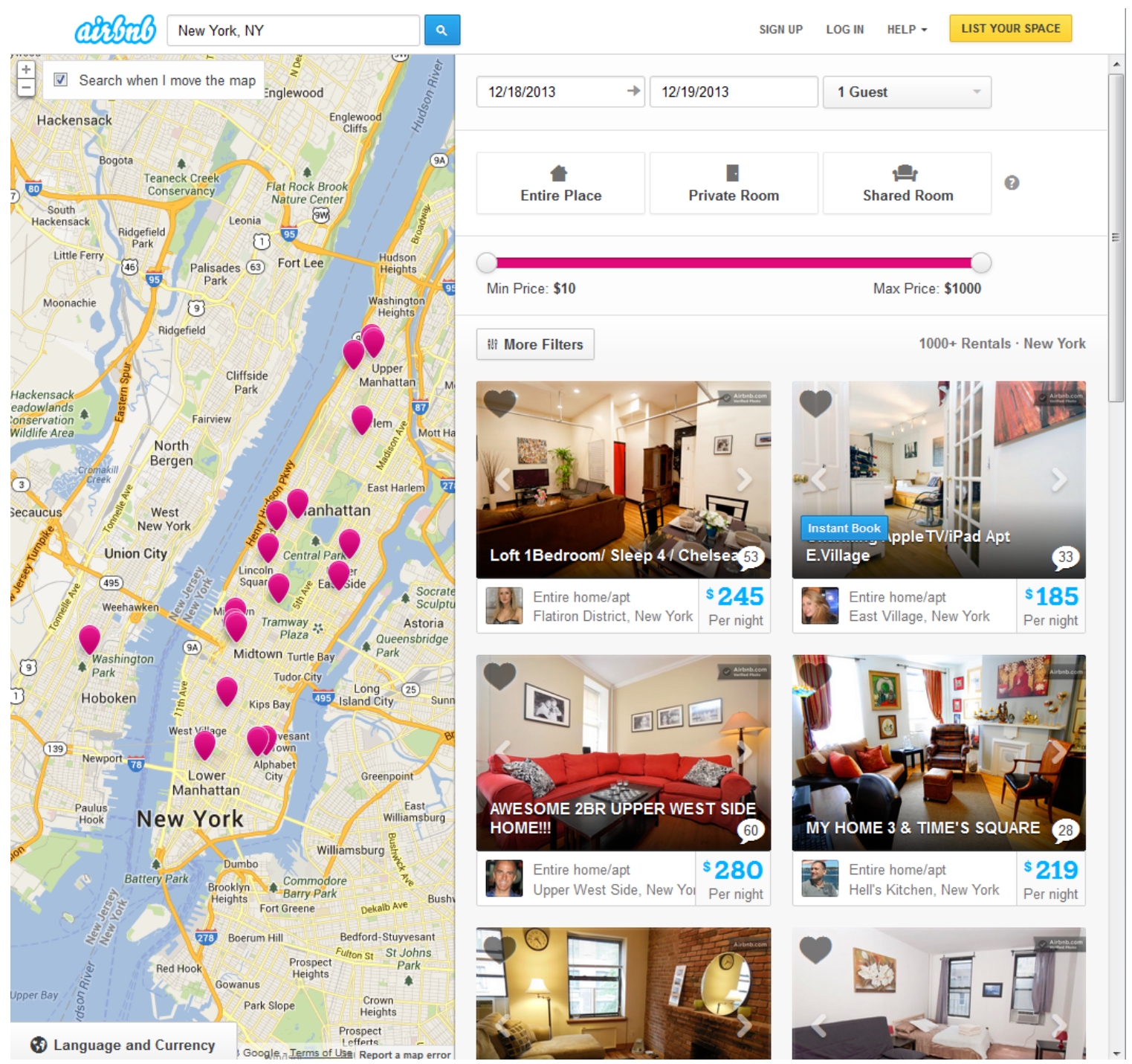

Source: Authors' use of Airbnb (December 8, 2013). 
Figure 1b: Search Filters

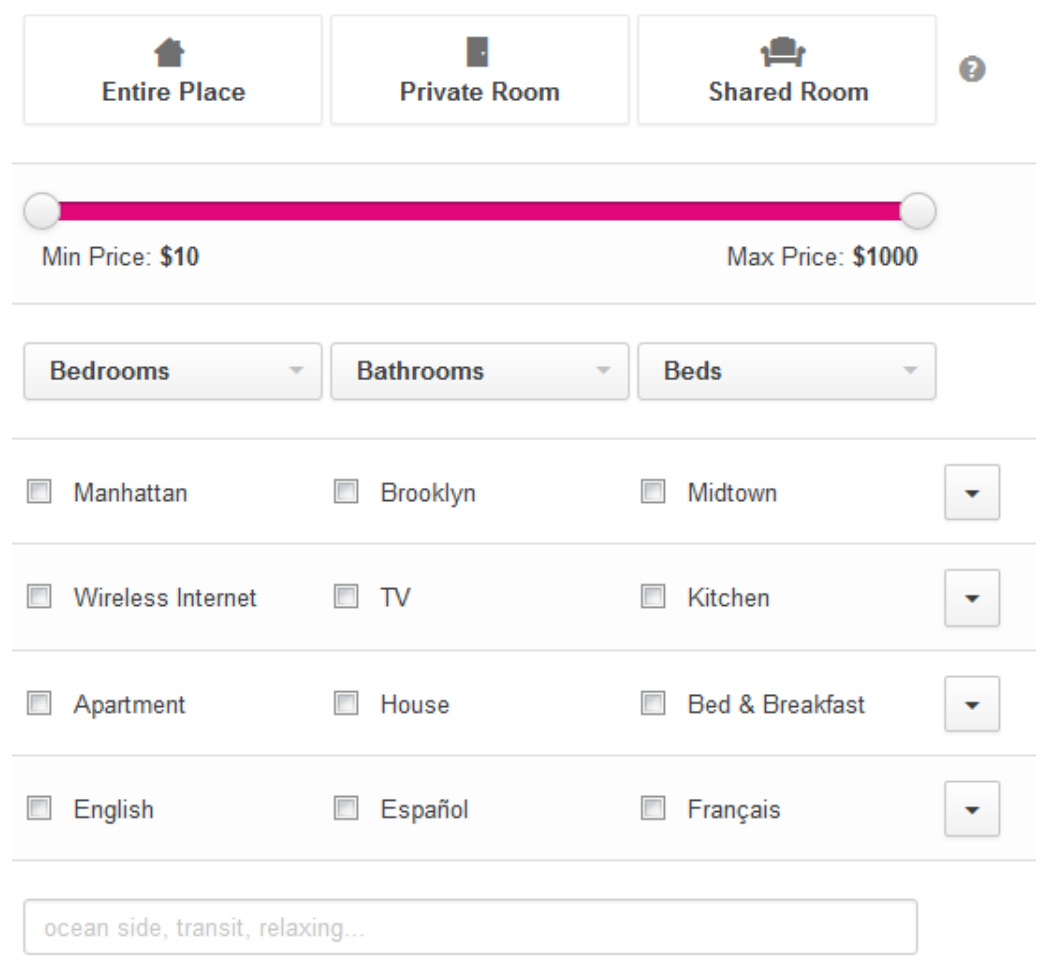

Note: Each triangular arrow yields a drop-down list allowing a guest to filter for specific options.

Source: Authors' use of Airbnb (December 8, 2013). 
Figure 1c: A sample property listing

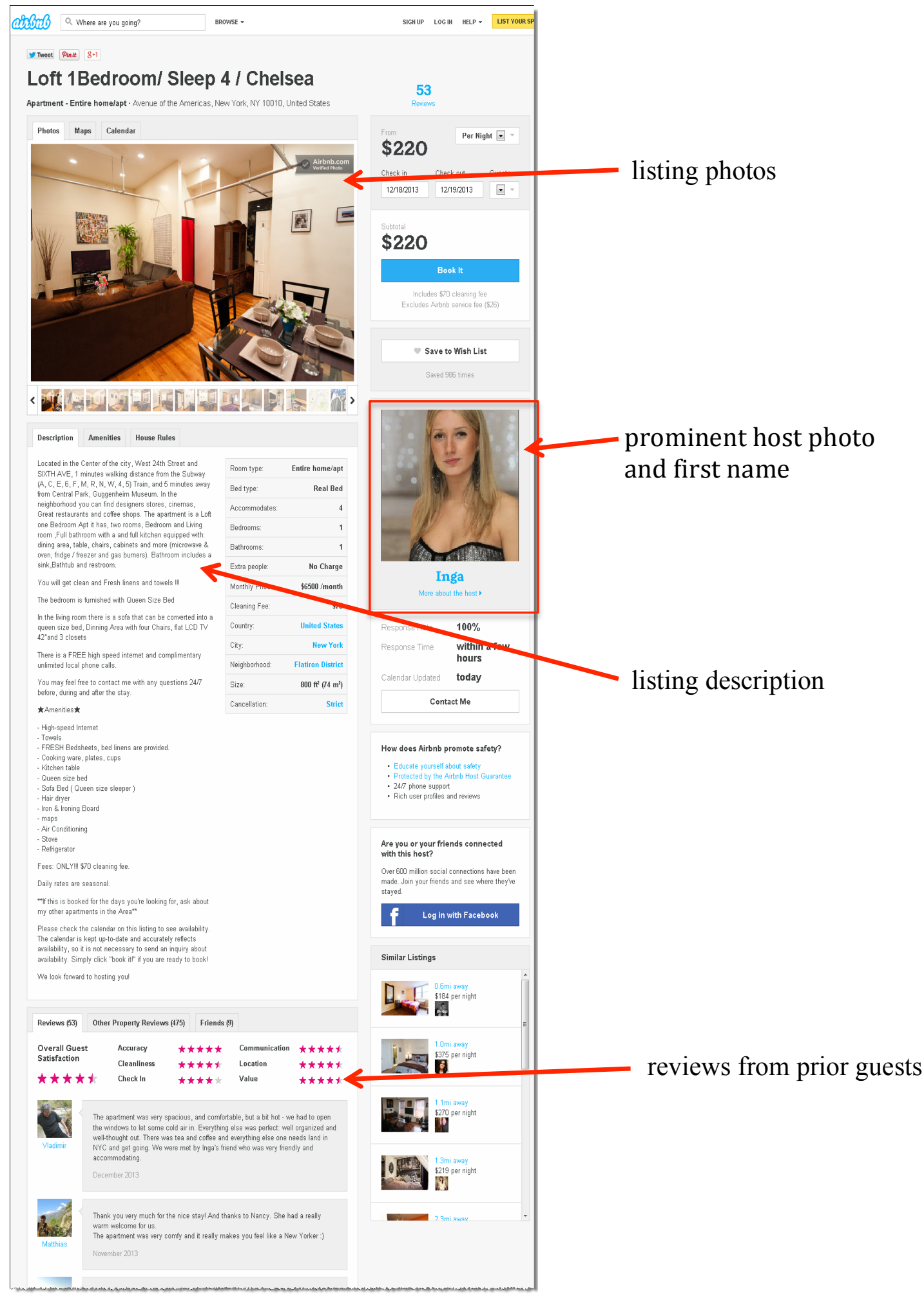

Source: Authors' use of Airbnb (December 8, 2013). 
Figure 2

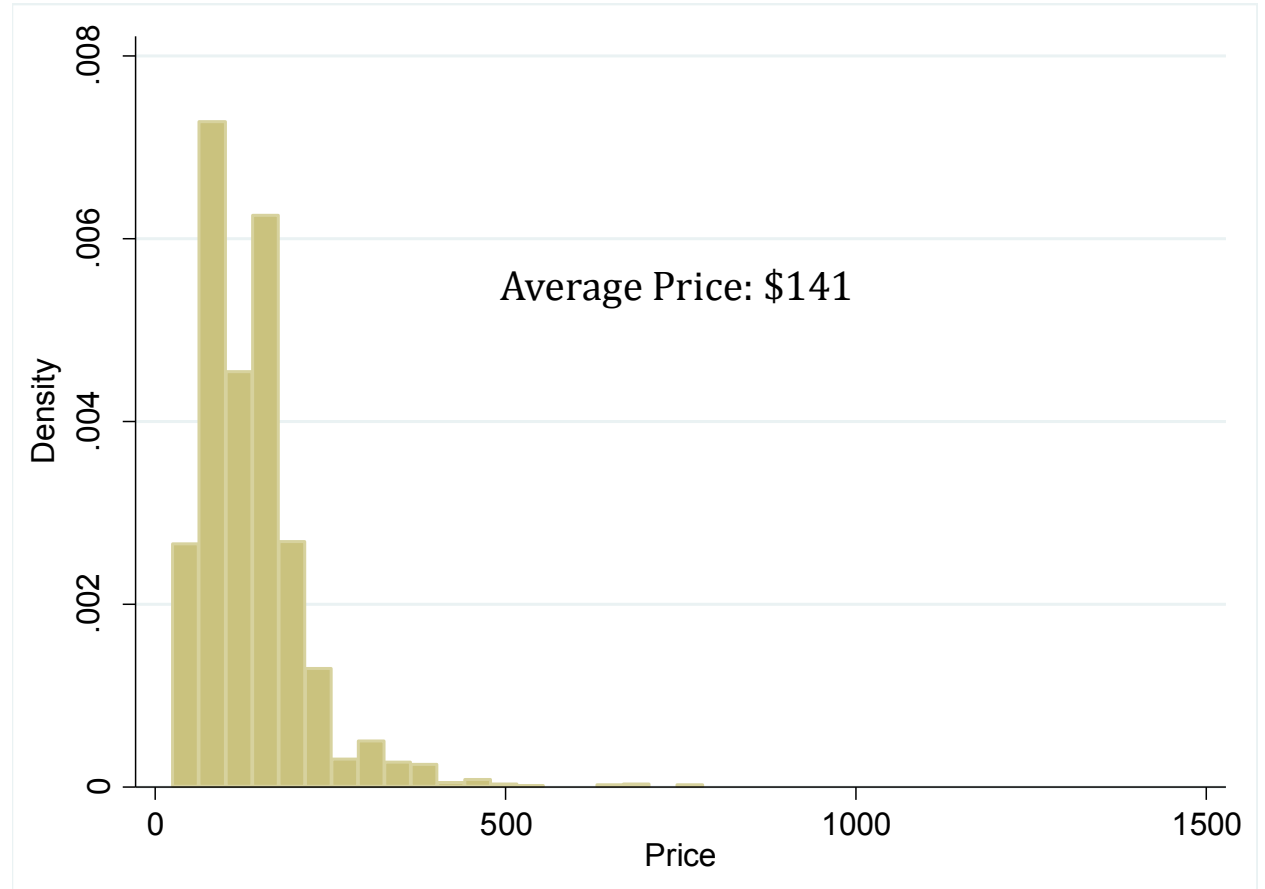

Figure 3
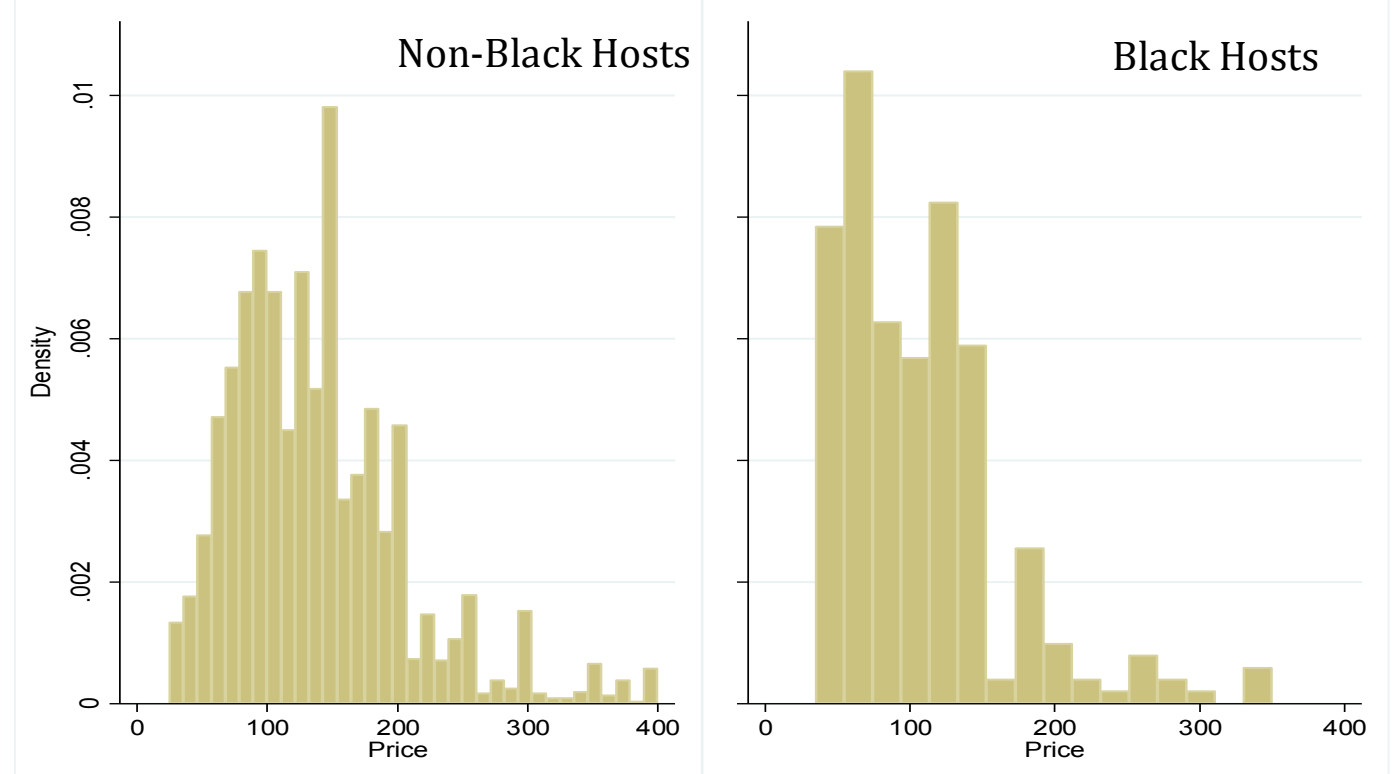


\section{Tables}

Table 1: Summary Statistics

\begin{tabular}{lcccccc}
\hline & & & \multicolumn{4}{c}{ Means among } \\
& \# Obs & Mean & SD & non-blacks & blacks & \\
\hline Black Host & 3752 & 0.07 & 0.25 & 0.00 & 1.00 \\
Price & 3752 & 141.35 & 85.58 & 143.88 & 107.27 & $6.68^{* * *}$ \\
Number Accommodated & 3746 & 3.09 & 1.73 & 3.10 & 3.07 & 0.20 \\
Whole Apartment & 3752 & 0.65 & 0.48 & 0.66 & 0.51 & $4.78^{* * *}$ \\
Number of Bedrooms & 3570 & 1.31 & 0.69 & 1.31 & 1.38 & $-1.66^{*}$ \\
Location Rating & 3752 & 8.12 & 3.15 & 8.16 & 7.59 & $2.82^{* * *}$ \\
Accuracy Rating & 3752 & 8.23 & 3.16 & 8.23 & 8.24 & -0.04 \\
Cleanliness Rating & 3752 & 7.96 & 3.12 & 7.95 & 8.08 & -0.65 \\
Communication Rating & 3752 & 8.50 & 3.23 & 8.50 & 8.57 & -0.35 \\
Check-In Rating & 3752 & 8.44 & 3.21 & 8.43 & 8.58 & -0.70 \\
Picture Quality & 3570 & 4.19 & 1.15 & 4.20 & 4.03 & $2.27 * *$ \\
\hline Observations & 3752 & & & 3493 & 259 & \\
\hline
\end{tabular}

T-test checks for a difference between the mean value of the characteristic for non-blacks versus blacks (two-sided). $* * * \mathrm{P}<0.01, * * \mathrm{P}<0.05$, $* \mathrm{P}<0.10$. 
Table 2: What determines listing prices?

\begin{tabular}{|c|c|c|c|c|c|c|}
\hline & \multicolumn{6}{|c|}{ Dependent Variable: Price } \\
\hline & $(1)$ & $(2)$ & (3) & (4) & $(5)$ & (6) \\
\hline Number & $9.605^{* * *}$ & $11.492^{* * *}$ & $11.647^{* * *}$ & $10.903^{* * *}$ & $10.824^{* * *}$ & $10.808^{* * *}$ \\
\hline Accommodated & $(1.30)$ & $(1.32)$ & $(1.32)$ & $(1.31)$ & $(1.30)$ & $(1.30)$ \\
\hline Whole Apartment & $\begin{array}{c}64.025^{* * *} \\
(1.97)\end{array}$ & $\begin{array}{c}52.292^{* * *} \\
(2.10)\end{array}$ & $\begin{array}{c}51.651^{* * *} \\
(2.12)\end{array}$ & $\begin{array}{c}50.222^{* * *} \\
(2.15)\end{array}$ & $\begin{array}{c}50.788^{* * *} \\
(2.13)\end{array}$ & $\begin{array}{c}50.945^{* * *} \\
(2.13)\end{array}$ \\
\hline 2 Bedrooms & $\begin{array}{l}2.314 \\
(3.30)\end{array}$ & $\begin{array}{c}-5.657^{*} \\
(3.27)\end{array}$ & $\begin{array}{c}-5.272 \\
(3.27)\end{array}$ & $\begin{array}{c}-5.915^{*} \\
(3.38)\end{array}$ & $\begin{array}{r}-5.106 \\
(3.35)\end{array}$ & $\begin{array}{r}-4.671 \\
(3.33)\end{array}$ \\
\hline 3 Bedrooms & $\begin{array}{c}-18.315^{* * *} \\
(6.83)\end{array}$ & $\begin{array}{c}-22.424^{* * *} \\
(6.99)\end{array}$ & $\begin{array}{c}-22.053^{* * *} \\
(7.06)\end{array}$ & $\begin{array}{c}-15.038^{* * *} \\
(5.13)\end{array}$ & $\begin{array}{c}-15.258^{* * *} \\
(5.04)\end{array}$ & $\begin{array}{c}-14.507^{* * *} \\
(5.19)\end{array}$ \\
\hline 4+ Bedrooms & $\begin{array}{c}-22.865^{* * *} \\
(5.21)\end{array}$ & $\begin{array}{c}-28.349^{* * *} \\
(4.63)\end{array}$ & $\begin{array}{c}-28.332^{* * *} \\
(4.58)\end{array}$ & $\begin{array}{c}-28.941^{* * *} \\
(4.69)\end{array}$ & $\begin{array}{c}-27.796^{* * *} \\
(4.61)\end{array}$ & $\begin{array}{c}-27.050^{* * *} \\
(4.60)\end{array}$ \\
\hline Location Rating & & $\begin{array}{c}22.497^{* * *} \\
(1.31)\end{array}$ & $\begin{array}{c}-63.213^{* * *} \\
(16.21)\end{array}$ & $\begin{array}{c}-74.325^{* * *} \\
(16.16)\end{array}$ & $\begin{array}{c}-72.798^{* * *} \\
(16.28)\end{array}$ & $\begin{array}{c}-71.155^{* * *} \\
(16.30)\end{array}$ \\
\hline Location Rating ^2 & & & $\begin{array}{c}4.904^{* * *} \\
(0.94)\end{array}$ & $\begin{array}{c}5.475^{* * *} \\
(0.93)\end{array}$ & $\begin{array}{c}5.397^{* * *} \\
(0.94)\end{array}$ & $\begin{array}{c}5.303^{* * *} \\
(0.94)\end{array}$ \\
\hline Check-In Rating & & $\begin{array}{l}-1.866 \\
(2.43)\end{array}$ & $\begin{array}{l}-1.239 \\
(2.34)\end{array}$ & $\begin{array}{l}-0.140 \\
(2.42)\end{array}$ & $\begin{array}{l}-0.211 \\
(2.41)\end{array}$ & $\begin{array}{l}-0.292 \\
(2.39)\end{array}$ \\
\hline Communication Rating & & $\begin{array}{l}-2.199 \\
(2.52)\end{array}$ & $\begin{array}{l}-2.100 \\
(2.51)\end{array}$ & $\begin{array}{l}-1.531 \\
(2.54)\end{array}$ & $\begin{array}{l}-1.606 \\
(2.53)\end{array}$ & $\begin{array}{l}-1.537 \\
(2.53)\end{array}$ \\
\hline Cleanliness Rating & & $\begin{array}{l}1.141 \\
(1.40)\end{array}$ & $\begin{array}{l}1.114 \\
(1.40)\end{array}$ & $\begin{array}{l}-0.737 \\
(1.42)\end{array}$ & $\begin{array}{l}-0.542 \\
(1.42)\end{array}$ & $\begin{array}{l}-0.559 \\
(1.42)\end{array}$ \\
\hline Accuracy Rating & & $\begin{array}{l}2.118 \\
(1.76)\end{array}$ & $\begin{array}{l}2.544 \\
(1.75)\end{array}$ & $\begin{array}{l}1.440 \\
(1.75)\end{array}$ & $\begin{array}{l}1.341 \\
(1.73)\end{array}$ & $\begin{array}{l}1.166 \\
(1.72)\end{array}$ \\
\hline Has LinkedIn & & $\begin{array}{c}10.193^{* * *} \\
(3.28)\end{array}$ & $\begin{array}{c}8.929^{* * * *} \\
(3.29)\end{array}$ & $\begin{array}{c}8.664^{* * * *} \\
(3.26)\end{array}$ & $\begin{array}{c}8.455^{* * * *} \\
(3.25)\end{array}$ & $\begin{array}{c}8.404^{* * *} \\
(3.24)\end{array}$ \\
\hline Has Facebook & & $\begin{array}{c}0.006^{* *} \\
(0.00)\end{array}$ & $\begin{array}{c}0.006^{* *} \\
(0.00)\end{array}$ & $\begin{array}{c}0.006^{* *} \\
(0.00)\end{array}$ & $\begin{array}{l}0.005^{*} \\
(0.00)\end{array}$ & $\begin{array}{c}0.006^{* *} \\
(0.00)\end{array}$ \\
\hline Has Phone Number & & $\begin{array}{c}12.282^{* * *} \\
(4.52)\end{array}$ & $\begin{array}{c}12.990^{* * *} \\
(4.48)\end{array}$ & $\begin{array}{c}13.583^{* * *} \\
(4.64)\end{array}$ & $\begin{array}{c}12.543^{* * *} \\
(4.61)\end{array}$ & $\begin{array}{c}12.338^{* * *} \\
(4.64)\end{array}$ \\
\hline Has Twitter & & $\begin{array}{c}0.001 \\
(0.00)\end{array}$ & $\begin{array}{c}0.001 \\
(0.00)\end{array}$ & $\begin{array}{c}0.001 \\
(0.00)\end{array}$ & $\begin{array}{l}0.001 \\
(0.00)\end{array}$ & $\begin{array}{l}0.002 \\
(0.00)\end{array}$ \\
\hline Picture Quality & & & & $\begin{array}{c}11.909^{* * *} \\
(1.04)\end{array}$ & $\begin{array}{l}-8.066 \\
(4.98)\end{array}$ & \\
\hline Picture Quality ^2 & & & & & $\begin{array}{c}2.415^{* * *} \\
(0.65)\end{array}$ & \\
\hline $\begin{array}{l}\text { Picture Rating } \\
\text { Indicators }\end{array}$ & & & & & & Yes \\
\hline $\begin{array}{l}\text { Apartment Size - } \\
\text { Whole Apartment } \\
\text { Interactions }\end{array}$ & Yes & Yes & Yes & Yes & Yes & Yes \\
\hline Constant & $\begin{array}{c}62.988^{* * *} \\
(2.97) \\
\end{array}$ & $\begin{array}{c}66.735^{* * *} \\
(3.97) \\
\end{array}$ & $\begin{array}{c}66.402^{* * *} \\
(3.97) \\
\end{array}$ & $\begin{array}{c}24.231^{* * *} \\
(5.28) \\
\end{array}$ & $\begin{array}{c}62.230^{* * *} \\
(9.44) \\
\end{array}$ & $\begin{array}{c}49.449^{* * *} \\
(7.23) \\
\end{array}$ \\
\hline
\end{tabular}

Note: Standard errors are reported in parentheses. $* * * \mathrm{P}<0.01, * * \mathrm{P}<0.05, * \mathrm{P}<0.10$. 
Table 3: Black hosts earn less for similar listings

\begin{tabular}{|c|c|c|c|c|c|c|c|}
\hline & \multicolumn{7}{|c|}{ Dependent Variable: Price } \\
\hline & (1) & (2) & (3) & (4) & (5) & (6) & (7) \\
\hline Black Host & $\begin{array}{c}-36.611^{* * *} \\
(3.88)\end{array}$ & $\begin{array}{c}-30.521^{* * *} \\
(3.72)\end{array}$ & $\begin{array}{c}-16.108^{* * *} \\
(3.46)\end{array}$ & $\begin{array}{c}-17.378^{* * *} \\
(3.47)\end{array}$ & $\begin{array}{c}-17.873^{* * *} \\
(3.46)\end{array}$ & $\begin{array}{c}-17.574^{* * *} \\
(3.47)\end{array}$ & $\begin{array}{c}-17.762^{* * *} \\
(3.47)\end{array}$ \\
\hline $\begin{array}{l}\text { Number } \\
\text { Accommodated }\end{array}$ & & $\begin{array}{c}9.656^{* * *} \\
(1.28)\end{array}$ & $\begin{array}{c}11.439^{* * *} \\
(1.31)\end{array}$ & $\begin{array}{c}11.599^{* * *} \\
(1.31)\end{array}$ & $\begin{array}{c}10.852^{* * *} \\
(1.30)\end{array}$ & $\begin{array}{c}10.776^{* * *} \\
(1.29)\end{array}$ & $\begin{array}{c}10.762^{* * *} \\
(1.29)\end{array}$ \\
\hline Whole Apartment & & $\begin{array}{c}61.726^{* * *} \\
(2.01)\end{array}$ & $\begin{array}{c}51.631^{* * *} \\
(2.11)\end{array}$ & $\begin{array}{c}50.902^{* * *} \\
(2.13)\end{array}$ & $\begin{array}{c}49.433^{* * *} \\
(2.16)\end{array}$ & $\begin{array}{c}50.003^{* * *} \\
(2.14)\end{array}$ & $\begin{array}{c}50.154^{* * *} \\
(2.14)\end{array}$ \\
\hline 2 Bedrooms & & $\begin{array}{l}-0.289 \\
(3.33)\end{array}$ & $\begin{array}{c}-6.749^{* *} \\
(3.27)\end{array}$ & $\begin{array}{c}-6.429^{* *} \\
(3.27)\end{array}$ & $\begin{array}{c}-7.154^{* *} \\
(3.38)\end{array}$ & $\begin{array}{c}-6.337^{*} \\
(3.36)\end{array}$ & $\begin{array}{c}-5.933^{*} \\
(3.33)\end{array}$ \\
\hline 3 Bedrooms & & $\begin{array}{c}-18.398^{* * *} \\
(7.02)\end{array}$ & $\begin{array}{c}-22.043^{* * *} \\
(7.10)\end{array}$ & $\begin{array}{c}-21.622^{* * *} \\
(7.18)\end{array}$ & $\begin{array}{c}-14.114^{* * *} \\
(5.28)\end{array}$ & $\begin{array}{c}-14.346^{* * *} \\
(5.21)\end{array}$ & $\begin{array}{c}-13.466^{* *} \\
(5.35)\end{array}$ \\
\hline 4+ Bedrooms & & $\begin{array}{c}-25.743^{* * *} \\
(5.20)\end{array}$ & $\begin{array}{c}-29.711^{* * *} \\
(4.63)\end{array}$ & $\begin{array}{c}-29.801^{* * *} \\
(4.58)\end{array}$ & $\begin{array}{c}-30.560^{* * *} \\
(4.68)\end{array}$ & $\begin{array}{c}-29.405^{* * *} \\
(4.60)\end{array}$ & $\begin{array}{c}-28.710^{* * *} \\
(4.59)\end{array}$ \\
\hline Location Rating & & & $\begin{array}{c}21.448^{* * *} \\
(1.33)\end{array}$ & $\begin{array}{c}-69.085^{* * *} \\
(16.32)\end{array}$ & $\begin{array}{c}-80.137^{* * *} \\
(16.36)\end{array}$ & $\begin{array}{c}-78.536^{* * *} \\
(16.48)\end{array}$ & $\begin{array}{c}-76.837^{* * *} \\
(16.46)\end{array}$ \\
\hline Location Rating ^2 & & & & $\begin{array}{c}5.175^{* * *} \\
(0.94)\end{array}$ & $\begin{array}{c}5.740^{* * *} \\
(0.94)\end{array}$ & $\begin{array}{c}5.658^{* * *} \\
(0.95)\end{array}$ & $\begin{array}{c}5.561^{* * *} \\
(0.95)\end{array}$ \\
\hline Check-In Rating & & & $\begin{array}{l}-1.584 \\
(2.42)\end{array}$ & $\begin{array}{l}-0.899 \\
(2.34)\end{array}$ & $\begin{array}{l}0.213 \\
(2.41)\end{array}$ & $\begin{array}{l}0.137 \\
(2.40)\end{array}$ & $\begin{array}{l}0.057 \\
(2.39)\end{array}$ \\
\hline Communication Rating & & & $\begin{array}{l}-2.384 \\
(2.51)\end{array}$ & $\begin{array}{l}-2.294 \\
(2.51)\end{array}$ & $\begin{array}{l}-1.735 \\
(2.53)\end{array}$ & $\begin{array}{l}-1.805 \\
(2.52)\end{array}$ & $\begin{array}{l}-1.731 \\
(2.52)\end{array}$ \\
\hline Cleanliness Rating & & & $\begin{array}{l}1.352 \\
(1.40)\end{array}$ & $\begin{array}{l}1.340 \\
(1.40)\end{array}$ & $\begin{array}{l}-0.475 \\
(1.43)\end{array}$ & $\begin{array}{l}-0.287 \\
(1.42)\end{array}$ & $\begin{array}{l}-0.301 \\
(1.43)\end{array}$ \\
\hline Accuracy Rating & & & $\begin{array}{l}1.902 \\
(1.76)\end{array}$ & $\begin{array}{l}2.335 \\
(1.75)\end{array}$ & $\begin{array}{l}1.190 \\
(1.75)\end{array}$ & $\begin{array}{l}1.097 \\
(1.73)\end{array}$ & $\begin{array}{l}0.911 \\
(1.71)\end{array}$ \\
\hline Has LinkedIn & & & $\begin{array}{c}11.022^{* * *} \\
(3.30)\end{array}$ & $\begin{array}{c}9.753^{* * * *} \\
(3.30)\end{array}$ & $\begin{array}{c}9.558^{* * * *} \\
(3.27)\end{array}$ & $\begin{array}{c}9.336^{* * *} \\
(3.26)\end{array}$ & $\begin{array}{c}9.294^{* * *} \\
(3.25)\end{array}$ \\
\hline Has Facebook & & & $\begin{array}{c}0.006^{* *} \\
(0.00)\end{array}$ & $\begin{array}{c}0.006^{* *} \\
(0.00)\end{array}$ & $\begin{array}{c}0.006^{* *} \\
(0.00)\end{array}$ & $\begin{array}{c}0.005^{* *} \\
(0.00)\end{array}$ & $\begin{array}{c}0.006^{* *} \\
(0.00)\end{array}$ \\
\hline Has Phone Number & & & $\begin{array}{c}12.662^{* * *} \\
(4.49)\end{array}$ & $\begin{array}{c}13.439^{* * *} \\
(4.46)\end{array}$ & $\begin{array}{c}14.033^{* * *} \\
(4.62)\end{array}$ & $\begin{array}{c}13.001^{* * *} \\
(4.59)\end{array}$ & $\begin{array}{c}12.761^{* * * *} \\
(4.62)\end{array}$ \\
\hline Has Twitter & & & $\begin{array}{l}0.001 \\
(0.00)\end{array}$ & $\begin{array}{l}0.001 \\
(0.00)\end{array}$ & $\begin{array}{l}0.001 \\
(0.00)\end{array}$ & $\begin{array}{l}0.001 \\
(0.00)\end{array}$ & $\begin{array}{l}0.001 \\
(0.00)\end{array}$ \\
\hline Picture Quality & & & & & $\begin{array}{c}11.877^{* * *} \\
(1.04)\end{array}$ & $\begin{array}{l}-7.793 \\
(4.95)\end{array}$ & \\
\hline Picture Quality^2 & & & & & & $\begin{array}{c}2.379^{* * * *} \\
(0.65)\end{array}$ & \\
\hline $\begin{array}{l}\text { Picture Rating } \\
\text { Indicators }\end{array}$ & & & & & & & Yes \\
\hline $\begin{array}{l}\text { Apartment Size - } \\
\text { Whole Apartment } \\
\text { Interactions }\end{array}$ & Yes & Yes & Yes & Yes & Yes & Yes & Yes \\
\hline Constant & $\begin{array}{c}143.878^{* * *} \\
(1.47)\end{array}$ & $\begin{array}{c}66.388^{* * *} \\
(2.89)\end{array}$ & $\begin{array}{c}68.600^{* * *} \\
(3.99)\end{array}$ & $\begin{array}{c}68.395^{* * *} \\
(3.99)\end{array}$ & $\begin{array}{c}26.521^{* * *} \\
(5.27)\end{array}$ & $\begin{array}{l}63.903^{* * *} \\
(9.42)\end{array}$ & $\begin{array}{l}50.075^{* * *} \\
(7.21)\end{array}$ \\
\hline
\end{tabular}

Note: Standard errors are reported in parentheses. $* * * \mathrm{P}<0.01, * * \mathrm{P}<0.05, * \mathrm{P}<0.10$. 